\title{
Antibodies against Hsp60 and Hsp65 in the sera of women with ovarian cancer
}

\author{
Piotr Bodzek ${ }^{1 *}$, Robert Partyka ${ }^{3}$ and Aleksandra Damasiewicz-Bodzek ${ }^{2}$
}

\begin{abstract}
Background: The aim of this study was to evaluate the concentrations of lgG antibodies against Hsp60 and Hsp65 in sera of patients with ovarian cancer at various stages of clinical progress and for different histopathological types of disease.

Methods: Serum samples from 149 patients with ovarian carcinoma and 80 healthy women were investigated. The concentrations of anti-Hsp60 and anti-Hsp65 antibodies were determined using the enzyme-linked immunosorbent assay technique.

Results: The mean concentrations of anti-Hsp60 and anti-Hsp65 antibodies in the patients with ovarian cancer did not differ significantly from the mean levels in healthy women. Analysis in relation to the clinical progression stage showed that the concentrations of these antibodies were higher when the neoplastic process was less advanced and at early stages significantly higher than in control group. Mean concentrations of both antibodies were not significantly different in relation to the histological type of the ovarian cancer. The use of chemotherapy as a primary anticancer treatment did not cause a significant change in the concentration of anti-Hsp60 antibodies, but the mean level of anti-Hsp65 after this treatment was significantly higher than in control group.

Conclusions: The immunological response to Hsp60/65 is increased in early clinical stages of ovarian cancer and the level of anti-hsp60/65 antibodies may be then a helpful diagnostic marker. Even antibodies against highly homologous Hsps may be cross-reactive only partially and differ by some functional properties.
\end{abstract}

Keywords: Anti-Hsp60 and anti-Hsp65 in ovarian cancer

\section{Background}

Ovarian cancer is a frequent cause of death in women in highly developed countries. This is caused, on one hand, by too late diagnosis (no early clinical symptoms, no specific diagnostic markers), and on the other - by therapeutic problems, particularly at the late stage of disease. Most patients with advanced ovarian cancer respond well to initial chemotherapy, however, within two years chemoresistant recurrence follows.

In recent years considerable attention has been paid to the important role of heat shock proteins (Hsps) in various carcinogenesis processes and their participation in developing resistance to anticancer treatment [1]. Hsps are excessively expressed in numerous malignant neoplasms in humans, including genital cancers. They

\footnotetext{
* Correspondence: piotr@bodzek.pl

'Department of Gynaecology, Obstetrics and Oncological Gynaecology,

Medical University of Silesia, Batorego 15, 41-902 Bytom, Poland

Full list of author information is available at the end of the article
}

participate in tumour cells proliferation, their differentiation, invasion, metastasis, death and recognition by the immune system $[2,3]$. There is evidence that some Hsps, on one hand, protect cells against apoptosis inducing factors, like cytokines, ionising radiation or oxidative stress $[4,5]$, while on the other, excessive expression of these proteins induced by chronic cell stress may result in apoptosis inhibition and thus facilitate cell neoplastic transformation [3,5]. Moreover, chaperone molecules may then protect transformed neoplastic cells, renaturating their cell proteins damaged by cytostatic agents used in anticancer therapy (chemo- or radiotherapy), thus contributing to increased aggressiveness of neoplasm and its resistance to treatment (2).

The role of some Hsp in processes of cancerogenesis, including ovarian cancer, has been considerably well described. However, still little is known about a possible role of a protein of $60 \mathrm{kDa}-\mathrm{Hsp} 60$. Hsp60 is an evolutionary 
highly conserved protein, which analogues in prokaryotic cells include mycobacterial Hsp65. In most cells, human Hsp60 is present constitutively in mitochondria, where it plays a role in protein assembly, folding and transport [1]. In conditions stressful to a cell, however, not only changes in its intracellular distribution may occur, but also it may be expressed on a cell surface or released to the intercellular space, indicating a possible role of that protein as an intercellular signalling molecule. It also exhibits immunoregulatory properties by inducing a proinflammatory response in cells responsible for the innate immune response, like macrophages, dendritic cells or endothelial cells [6].

Extracellular forms of heat shock proteins, including Hsp60, also behave as autoantigens and induce host's Band T-cell immune response. Anti-Hsps antibodies can be found in healthy people and they can be treated as a part of the natural autoantibodies spectrum $[7,8]$. Their increased number can then reflect increased extracellular expression of shock proteins, caused by cells' specific pathologic conditions or their modified activity [7]. Anti-Hsps immunization may also be caused by heterologous Hsps, e.g. of bacterial origin, as some bacterial heat shock proteins, like Hsp65, are also surface antigens, against which antibodies are produced in the immune response process [9]. Considering their high inter-species conservatism, the immune response to heterologous Hsps may also be a source of cross-reactivity with autoantigens $[9,10]$. Increased levels of anti-Hsps antibodies have already been observed in many diseases, particularly resulting from autoagression (review in 7). It was also demonstrated that levels of circulating Hsps and antiHsps antibodies could be useful biomarkers for carcinogenesis in some tissues, as well as prognosis factors for survival and susceptibility to treatment $[2,7]$.

Presence of Hsp60 and anti-Hsp60/65 antibodies in serum of patients with ovarian cancer, however, still remains a new research field, and studies conducted so far often gave contradictory results. The aim of this study was, therefore, to evaluate levels of IgG antibodies against these proteins in serum of patients with ovarian cancer at different stages of clinical progress and with various histopathological types of disease.

\section{Material and methods}

The study included 149 women with ovarian cancer, hospitalised at the Department of Gynaecology, Obstetrics and Oncological Gynaecology of Medical University of Silesia in Bytom. Patients with co-occurring diseases, such as diabetes, advanced atherosclerosis, hypertension, etc., were excluded from the study. The control group consisted of 80 healthy women without any history of cancer.

The blood samples (about $5 \mathrm{ml}$ in volume) were obtained at 8.00 a.m., in the fasted state, from antecubital veins and they were centrifuged immediately. The collected sera had been stored at $-70^{\circ} \mathrm{C}$ until assays could be performed.

The study protocol was approved by the Local Bioethics Commission of the Medical University of Silesia in Katowice. All women included were informed about the aim of the study and gave their written consent for participation.

The concentrations of IgG antibodies against Hsp60 (anti-Hsp60) and Hsp65 (anti-Hsp65) in studied serum samples were determined with the enzyme-linked immunosorbent assay (ELISA). The antigens used were recombinant human Hsp60 (Enzo Life Sciences Inc., Farmingdale, NY) and recombinant Hsp65 from Mycobacterium bovis (Calbiochem, San Diego, CA). The ELISA plates (Maxisorp, Nunc, Denmark) were coated with antigen solution at a concentration $2 \mathrm{mg} / \mathrm{ml}$ of $50 \mathrm{mM}$ carbonate buffer at $\mathrm{pH}=9.6$. Studied sera were diluted $400 \times$ (optimal dilution was chosen experimentally) in $0.5 \%$ bovine serum albumin in phosphate buffered saline with Tween-20. Calibration was performed using pooled sera from about 100 of the healthy blood donors. The $400 \times$ dilution was assumed to correspond to 100 arbitral units $/ \mathrm{ml}$ $(\mathrm{AU} / \mathrm{ml})$. A calibration curve consisted of 6 standards, with levels from 0 to $400 \mathrm{AU} / \mathrm{ml}$. Incubation with studied sera and standards was conducted for 24 hours at $4^{\circ} \mathrm{C}$. For detection of bound IgG antibodies, a goat anti-human IgG antibody conjugated with a horseradish peroxidase (Sigma, St. Louis, MO) was used. A tetramethylbenzidine solution (Sigma, St. Louis, MO) was used as a substrate for an enzymatic reaction. Absorbances were read with the Power Wave XS plate reader (BioTek, Winooski, VT) at $450 \mathrm{~nm}$ (reference wavelength $-630 \mathrm{~nm}$ ), and results were processed with the KCJunior software (BioTek, Winooski, VT). The intra-assay variation was $8 \%$. Determinations were done during one series. The assay sensitivity was about $1 \mathrm{AU}$.

The obtained results were presented using basic descriptive statistics parameters. The accordance of the data distribution with the normal distribution was checked with the Szapiro-Wilk test. The groups were compared using non-parametric Kolmogorov-Smirnov and $U$ Mann-Whitney tests, and the test of differences between structure indications. For study of variability in the group of patients with ovarian cancer, the KruskalWallis ANOVA rank test was used. Correlations between parameters were assessed with the Spearmann's rank correlation test. The significance level of $\mathrm{p}<0.05$ was considered to be statistically significant. Calculations were conducted with the application STATISTICA for Windows, version 10.0, from StatSoft Inc. (Tulsa, OK).

\section{Results}

The mean age ( $56.2 \pm 10.5$ years) of studied women with ovarian cancer was comparable to the age ( $52.8 \pm 8.2$ years) 
of women in the control group ( $p>0.05$ ). Of 149 studied patients, in 72 patients ovarian cancer was diagnosed for the first time and they were not treated yet, while 77 patients already underwent previous anticancer chemotherapy. The studied group included patients with various histopathological forms of ovarian cancer and at different clinical stages. Their detailed characteristics are presented in Table 1.

The mean concentrations of anti-Hsp60 and antiHsp65 antibodies in the whole group of patients with ovarian cancer did not differ significantly from the mean levels of these antibodies in the control group of healthy women (Table 2). Positive results (values exceeding $90^{\text {th }}$ percentile for the control group) were observed in $21.8 \%$ patients with ovarian cancer for anti-Hsp60 levels and in $20.6 \%$ patients for anti-Hsp65 levels. In both cases, the percentage of values considered to be positive was significantly higher than in the control group.

The analysis depending on the disease clinical stage (FIGO) showed that the mean levels of anti-Hsp60 and anti-Hsp65 antibodies were higher when the neoplastic process was less advanced (Table 3 ). The mean concentrations of both antibodies in patients at the I and the II clinical stage are significantly higher than in the control group. The mean levels of both antibodies in patients at the I stage are significantly higher than at the III and the IV stages, and mean levels at the II stage are significantly higher than at the IV stage. The similar observations were done for the percentages of positive values (details in Table 3).

The mean levels of anti-Hsp60 and anti-Hsp65 antibodies in the patients with ovarian cancer did not differ significantly depending on the cancer histopathological type. In the patients with each histopathological type they also did not differ significantly from the mean levels of these antibodies in the control group. The percentages

Table 1 Clinical characteristics of examined women with ovarian cancer $(n=149)$

\begin{tabular}{ll}
\hline Clinical data & Number of patients (\%) \\
\hline Antineoplastic treatment: & $72(48,3)$ \\
• Untreated so far & $77(51,7)$ \\
• After chemotherapy & \\
Histopathological type of ovarian cancer: & $82(55,0)$ \\
• Adenocarcinoma papillare serosum & $44(29,6)$ \\
• Adenocarcinoma mucinosum & $23(15,4)$ \\
- Adenocarcinoma endometrioides & \\
Stage of the clinical progresion (by FIGO): & $25(16,8)$ \\
• I & $31(20,8)$ \\
• II & $60(40,3)$ \\
• III & $33(22,1)$ \\
• IV & \\
\hline
\end{tabular}

Table 2 Concentrations of anti-Hsp60 and anti-Hsp65 IgG antibodies in group of women with ovarian cancer and in control group

\begin{tabular}{|c|c|c|}
\hline & $\begin{array}{c}\text { Ovarian cancer } \\
n=149\end{array}$ & $\begin{array}{c}\text { Controls } \\
n=80\end{array}$ \\
\hline Anti-Hsp60 (AU/ml) & $93,91 \pm 127,75$ & $62,42 \pm 33,92$ \\
\hline \multicolumn{3}{|l|}{$($ mean $\pm S D)$} \\
\hline$\%$ of positive resullts & $21,8 \% *$ & $10 \%$ \\
\hline (> 90 percentile for control group) & $p=0.024$ & \\
\hline Anti-Hsp65 (AU/ml) & $97,06 \pm 169,95$ & $56,35 \pm 35,58$ \\
\hline \multicolumn{3}{|l|}{$($ mean $\pm S D)$} \\
\hline$\%$ of positive resullts & $20,6 \% *$ & $10 \%$ \\
\hline (> 90 percentile for control group) & $p=0,039$ & \\
\hline
\end{tabular}

of positive values for individual histopathological types of ovarian cancer were comparable (details in Table 4).

Use of chemotherapy as the primary anticancer treatment in ovarian cancer did not resulted in a significant change of anti-Hsp60 antibody levels, which were comparable to levels observed in the group of untreated patients and in the control group. The percentages of positive values in both studied groups of patients were also comparable (Table 5). In the group of patients after chemotherapy the mean anti-Hsp65 antibodies concentration was, however, significantly higher than in the healthy women. The percentages of positive values for anti-Hsp60 levels in the group of untreated patients, and for anti-Hsp65 levels in the group of patients after chemotherapy were also significantly higher than in the group of healthy women.

In both studied groups of women - the group with ovarian cancer and the control group of healthy women concentrations of studied antibodies were not significantly correlated with the age. Levels of anti-Hsp60 and anti-Hsp65 antibodies, however, were positively correlated with each other, both in the group of patients with ovarian cancer and in the control group of healthy women $(\mathrm{p}=0.0000, \mathrm{R}=0.35$ and $\mathrm{p}=0.0000, \mathrm{R}=0.62$, respectively).

\section{Discussion}

Ovarian cancer is responsible for as many as $55 \%$ of deaths related to malignant genital neoplasms and $6 \%$ of all deaths caused by malignant neoplasms in women $[11,12]$. The prognosis and the long-term survival have remained stable for a long time, mainly due to inadequate diagnostic procedures which usually detect that cancer only at its advanced stage (only $23 \%$ of cases are detected at the I stage) [12,13]. Also, a delayed diagnosis is often a consequence of lack of clinical symptoms which sometimes occur only after appearance of local and/or distant metastases [14]. Therefore, a key to 
Table 3 Concentrations of anti-Hsp60 and anti-Hsp65 IgG antibodies in group of women with ovarian cancer depending on stage of clinical disease progression (by FIGO) and in control group

\begin{tabular}{|c|c|c|c|c|c|}
\hline & \multicolumn{4}{|c|}{ Stage of clinical disease progression (by FIGO) } & \multirow{3}{*}{$\begin{array}{c}\text { Controls } \\
n=80\end{array}$} \\
\hline & I & II & III & IV & \\
\hline & $\mathrm{n}=\mathbf{2 5}$ & $\mathrm{n}=31$ & $\mathrm{n}=60$ & $\mathrm{n}=33$ & \\
\hline Anti-Hsp60 (AU/ml) & $126,99^{\mathrm{a} b \mathrm{~b}) \mathrm{e}}$ & $97,15^{\text {c)e }}$ & 91,92 & 70,87 & 62,42 \\
\hline$($ mean $\pm S D)$ & $\pm 121,90$ & $\pm 91,82$ & $\pm 160,11$ & $\pm 78,70$ & $\pm 33,92$ \\
\hline$\%$ of positive results & $46 \%{ }^{\oplus}$ & $27 \%^{\dagger}$ & $17 \%$ & $17 \%$ & $10 \%$ \\
\hline (> 90 percentile for control group) & $p=0.0000$ & $p=0.0213$ & $p=0.2047$ & $p=0.2861$ & \\
\hline Anti-Hsp65 (AU/ml) & $190,34^{\mathrm{a}) \mathrm{b}) e)}$ & $97,80^{\text {c)e) }}$ & $89,36^{d)}$ & 44,17 & 56,35 \\
\hline$($ mean $\pm S D)$ & $\pm 337,27$ & $\pm 90,59$ & $\pm 137,58$ & $\pm 26,07$ & $\pm 35,58$ \\
\hline$\%$ of positive results & $46 \%{ }^{\oplus}$ & $27 \%{ }^{\oplus)}$ & $21 \%$ & $0 \%^{\oplus}$ & $10 \%$ \\
\hline (> 90 percentile for control group) & $p=0.0000$ & $p=0.0213$ & $p=0.0594$ & $p=0.0493$ & \\
\hline
\end{tabular}

a) $p<0.05$ in group of women with I clinical stage compared to group of women with III clinical stage.

b) $p<0.05$ in group of women with I clinical stage compared to group of women with IV clinical stage.

c) $p<0.05$ in group of women with II clinical stage compared to group of women with IV clinical stage.

d) $p<0.05$ in group of women with III clinical stage compared to group of women with IV clinical stage.

e) $p<0.05$ in group of women with I and II clinical stage compared to control group.

${ }^{\text {f) }} \mathrm{p}<0.05$ in group of women with I, II and IV clinical stage compared to control group.

significant improvement in treatment results and the prognosis in ovarian cancer is finding methods for early detection of that neoplasm [13]. Expression of CA125 antigen is limited at early stages of ovarian cancer and may also be related to non-malignant lesions; therefore, its prognostic value is only $57 \%$ [15]. Determination of that antigen is an example of a method based on detection of circulating tumour-associated antigens - specific proteins released to the circulatory system by neoplastic cells due to their excessive or incorrect expression. Such antigens first have to saturate immunologic antigenprocessing capacity and then reach detectable and stable circulating levels, and that occurs only after some time from neoplastic transformation [16]. Excessive or modified expression of specific tumour-associated antigens can also be a source of autoimmunization and antibodies production $[17,18]$. Presence of antibodies reactive to tumour-associated antigens can be showed in the circulation already at early stages of its development, and much earlier than circulating antigens [19-21]. Furthermore, antibody stability is much higher than other serum biomarkers and less susceptible to effects of various disturbing agents $[19,20,22]$, thus the tumourreactive antibodies seem to be a more useful diagnostic marker, particularly at early stages of neoplasm development, than tumour-derived antigens [13]. Presence of antibodies against tumour-associated antigens in serum was already demonstrated in patients with various neoplasms [23-25], including ovarian cancer [13,18,26,27]. They were detectable already at early stages of tumour development and related to its progress, as well as allowed distinguishing between benign and malignant lesions (13). However, comparing to other malignant neoplasms, a relatively small number of antigens related to

Table 4 Concentrations of anti-Hsp60 and anti-Hsp65 IgG antibodies in group of women with ovarian cancer depending on histopathological type of tumor and in control group

\begin{tabular}{lccc}
\hline & \multicolumn{1}{c}{ Ovarian cancer } & Controls \\
\cline { 2 - 4 } & $\begin{array}{c}\text { Adenocarcinoma papillare } \\
\text { serosum } \\
\mathbf{n}=\mathbf{8 2}\end{array}$ & $\begin{array}{c}\text { Adenocarcinoma } \\
\text { mucinosum } \\
\mathbf{n}=\mathbf{4 4}\end{array}$ & $\begin{array}{c}\text { Adenocarcinoma } \\
\text { endometrioides }\end{array}$ \\
$\mathbf{n}=\mathbf{2 3}$
\end{tabular}

${ }^{*} \mathrm{p}<0.05$ in group of women with ovarian cancer compared to control group. 
Table 5 Concentrations of anti-Hsp60 and anti-Hsp65 IgG antibodies in group of women with ovarian cancer depending on treatment phase and in control group

\begin{tabular}{|c|c|c|c|}
\hline & \multicolumn{2}{|c|}{ Phase of antineoplastic treatment } & \multirow{3}{*}{$\begin{array}{c}\text { Controls } \\
n=80\end{array}$} \\
\hline & Untreated so far & After chemotherapy & \\
\hline & $n=72$ & $n=77$ & \\
\hline Anti-Hsp60 (AU/ml) & $89,59 \pm 89,99$ & $99,91 \pm 158,40$ & $62,42 \pm 33,93$ \\
\hline \multicolumn{4}{|l|}{ (mean $\pm \mathrm{SD})$} \\
\hline$\%$ of positive results & $28 \% *$ & $19 \%$ & $10 \%$ \\
\hline (> 90 percentile for control group) & $p=0.0041$ & $p=0.1085$ & \\
\hline Anti-Hsp65 (AU/ml) & $80,31 \pm 86,71$ & $109,64 \pm 226,24$ & $56,35 \pm 35,57$ \\
\hline \multicolumn{4}{|l|}{ (mean $\pm \mathrm{SD})$} \\
\hline$\%$ of positive results & $19 \%$ & $22 \% *$ & $10 \%$ \\
\hline (> 90 percentile for control group) & $p=0.1103$ & $p=0.0398$ & \\
\hline
\end{tabular}

${ }^{*} \mathrm{p}<0.05$ in group of women with ovarian cancer compared to control group.

ovarian cancer were found and there is really a small number of studies on antibodies against tumour-associated antigens in ovarian cancer [21]. It seems then that searching for such specific antibodies and their quantitative evaluation may be a key for developing better methods for early diagnosis of that neoplasm.

Recent years have brought many valuable reports on a significant role of heat shock proteins in development of malignant processes, also within the ovary. That role mainly concerns facilitation of malignant transformation, progression of tumour cell survival and contribution to development of resistance to anticancer therapy [1]. However, it is still unknown why Hsps are excessively expressed in tumour cells. Is it caused by an adverse microenvironment of the tumour itself (defensive cellular response) or does it result from genetic modifications related to malignant transformation [28] Neoplastic cells seem to be resistant to pro-apoptotic signals, and as Hsps play an important and comprehensive role in apoptosis processes and at the same time are expressed excessively in malignant cells, they are a subject of intensive research, both as possible therapeutic targets and as prognostic and diagnostic markers [2]. It was proved that excessive expression of various Hsps was related to bad prognosis and poor response to therapy in various types of malignant neoplasms, including ovarian cancer (reviewed in 2). Some Hsps were identified as tumourassociated antigens recognised by antibodies present in serum of patients with ovarian cancer [21], and Hsp27, Hsp70 and Hsp90 expression in tumour tissues was positively correlated to the clinical stage of disease (FIGO) [29]. One of Hsps, which role in malignant neoplastic processes is relatively poorly known, is Hsp60. It seems that in case of prostate cancer increased expression of that protein occurs at an early stage of malignant phenotype development [30], and in rectal and cervical cancers these expression levels increase with malignancy
[31,32]. The latest studies showed that in ovarian cancer Hsp60 expression in tumour tissues visibly increased versus expression in correct ovarian tissues [33] and high expression of this protein is also related to poorer prognosis and higher risk of tumour progression [34,35]. Increased levels of anti-Hsp60 antibodies were found in sera of patients with osteosarcomas [36]. The mean concentrations of anti-Hsp60 and anti-Hsp65 antibodies in our group of patients with ovarian cancer were higher than in the control group, but that difference did not reach the statistical significance level. In the group of patients, however, the values considered as positive occurred significantly more often. A very interesting observation was made when the group of women with ovarian cancer was divided depending on the clinical stage of disease (FIGO I - IV). It showed that at the early stages, the mean levels of both studied antibodies were significantly higher than in healthy women and significantly higher than at later stages. The same applies to the occurrence of positive values, which in the group of patients at the I stage occurred in as many as $46 \%$ of patients, while in the group of patients at the II stage - in $27 \%$ of patients. This observation may point that antigenicity of the tumour changes during neoplastic process or the specific tolerance develops to that antigen, and thus B-cell reactions are weakened. These results indicate usefulness of assessment of anti-Hsp60/65 antibody levels as a diagnostic marker especially at early clinical stages of the disease, when lack of specific markers in serum and lack of clinical symptoms often delay diagnosis. Similar observations were also already made in ovarian cancer for anti-Hsp27 antibodies. In the patients at the I and the II clinical stage of disease the ratio of positive results was $62 \%$ and $55 \%$, respectively [37]. Contrary, presence of anti-Hsp90 antibodies is related to later ovarian cancer stages [38]. The mean anti-Hsp60 and anti-Hsp65 antibodies levels did not varied 
depending on tumour histopathological type, although individual histopathological types differed in positive value ratios.

Recently, a lot is being said about heat shock proteins involvement in development of tumour resistance to non-surgical treatment, and resistance to chemotherapy is one of fundamental problems in treatment of patients with advanced ovarian cancer. One of proteins suspected of participation in development of resistance to chemotherapeutics is Hsp60. Increased expression of this protein was correlated to resistance to cisplatin in various ovarian cancer cell lines [39]. A weak response or even resistance to chemotherapy in ovarian cancer cells also results from increased Hsp27 expression [40]. Hsp60, Hsp27 (and other Hsps) involvement in development of tumour resistance to chemotherapy may result from several mechanisms. As chaperone molecules, they can have cytoprotective effect also on neoplastic transformed cells, "repairing" their proteins damaged by cytotoxic effect of drugs [2] or increasing repair processes in damaged DNA [41,42]. Many authors are of the opinion that the crucial mechanism is, however, protection of tumour cells against apoptosis. The studies suggest this may occur at several stages, through interference with both internal and external apoptosis pathways [4]. Following an analysis of our results it seems that administration of chemotherapy as primary anticancer treatment has no significant effect on anti-Hsp60 antibodies level. An interesting observation concerns, on the other hand, levels of anti-Hsp65 antibodies, which mean value in the group of patients after chemotherapy is significantly higher than in the control group. Anti-Hsp60 and anti-Hsp65 antibodies are extensively described in the literature as cross-reacting antibodies [43,44] due to phylogenetic similarity between forms of these proteins in microorganisms and in mammals. Observations that increased levels of antibodies against mycobacterial Hsp65 (75\% homologous with human Hsp60) are related to vascular diseases severity and progress $[45,46]$ resulted in assumptions that immunization against heat shock proteins also affects development and progress of atherosclerosis [47]. As anti-Hsp65 antibodies mediate cytotoxicity against human endothelial cells through cross-reaction with Hsp60 on their surface, damage of vascular cells could result from such reactions in vivo [48]. When levels of antiHsp60 and anti-Hsp65 antibodies are assessed simultaneously, usually strong correlation is found between their values $[49,50]$. In studied by us groups of women that were either healthy or had ovarian cancer, levels of these antibodies were also significantly correlated, although the strength of positive correlation was higher in healthy women ( $R=0.62$ vs. $R=0.35$ ). Without excluding the cross-reactions mentioned, our results may, however, indicate a diverse nature of both antibodies, e.g., the fact that their cross-reactiveness is only partial. They can recognise different parts of the antigen and have different functional properties. Prohaszka et al. [51] drew similar conclusions from their research, in which they showed differences between anti-Hsp60 and anti-Hsp65 in antigen recognition, complement activation and specificity. Also Handley et al. [52] observed that anti-Hsp60 antibodies present in serum of healthy persons and patients with various autoimmune diseases were competitively inhibited by Hsp60, but only slightly, or not at all, by mycobacterial Hsp65. Research of Metzler et al. [53] showed that antibodies in human serum reacting with human Hsp60 and/or mycobacterial Hsp65 recognised at least three different epitopes in mycobacterial protein. Different functional properties of both antibodies were also proved by research of Birnie et al. [54], who observed that increased levels of anti-Hsp60 antibodies indicated poor prognosis for patients with acute chest pain, while antibodies against mycobacterial Hsp65 had no prognostic value. Significantly higher levels of anti-Hsp65 antibodies in the group of patients with ovarian cancer after chemotherapy, with the mean levels of anti-Hsp60 antibodies comparable to the control group, may also indicate that protein antigenicity was modified by treatment. Possibly post-translational modifications caused in endogenous Hsp60 by chemotherapy, make it homologically more similar to its mycobacterial equivalent, while Hsp60 used in the ELISA test is recombinant protein without these modifications.

There is reactivity and/or cross-reactivity between anti-Hsps antibodies and exogenous Hsps of bacterial origin and endogenous host Hsps, including Hsps circulating in plasma, Hsps present inside cells and on their surface (also neoplastic cells) and Hsps in the extracellular space. These antibodies may control the inflammatory response either positively or negatively, it seems however, they can also have various specific functions in different pathological conditions [7]. Even antibodies against highly homologous Hsps (like human Hsp60 and mycobacterial Hsp65) may be cross-reactive only partially and differ by some functional properties. Detailed knowledge of these differences and properties remains a challenge for the future, particularly considering Hsps and anti-Hsps antibodies involvement in carcinogenesis and neoplasm progression processes, development of metastases and resistance to treatment. Our data indicates that high serum concentrations of anti-Hsp60/65 antibodies are particularly characteristic for early clinical stages of ovarian cancer. However, as they can also be present in healthy persons [55], there is a need to determine the cut-off value and to learn how to distinguish between "normality" and disease using sensitive quantitative techniques [7]. The proposed ELISA technique seems to be such technique. Although diagnostic levels of anti-Hsp60/65 antibodies have not been precisely 
defined yet, we can assume usefulness of that marker in detection of ovarian cancer, particularly at early clinical stages. The nature of the anti-Hsp immune response in malignant transformation and role of autoantibodies in that process remain to be clarified - is their presence serves as anticancer defence, and if so, whether they can be used as new therapeutic strategies in oncology.

\section{Competing interests}

The authors declare that they have no competing interests.

\section{Authors' contributions}

PB: author of the concept and principles of work, gathering material, developing the concept and principles of research, laboratory test, description of test results, preparation of literature, co author of the text. RP: author responsible the manuscript, final verification and approval of manuscript, revision and update of literature. AD-B: statistical analysis of results, preparation of the manuscript. All authors read and approved the final manuscript.

\section{Acknowledgements}

This study was supported by a research grant (no. KNW-2-106/10) from the Medical University of Silesia in Katowice.

We would like to thank very much dr Tomasz Wielkoszyński for his valuable methodological help.

\section{Author details}

'Department of Gynaecology, Obstetrics and Oncological Gynaecology, Medical University of Silesia, Batorego 15, 41-902 Bytom, Poland. ${ }^{2}$ Department of Chemistry, Medical University of Silesia, Zabrze, Poland. ${ }^{3}$ Department of Anesthesiology, Intensive Treatment and Emergency Medicine, Medical University of Silesia, Katowice, Poland.

Received: 10 January 2014 Accepted: 15 February 2014

Published: 11 March 2014

\section{References}

1. Cohen M, Dromard M, Petignat P: Heat shock proteins in ovarian cancer: a potential target for therapy. Gynecol Oncol 2010, 119:164-166.

2. Ciocca DR, Calderwood SK: Heat shock proteins in cancer: diagnostic, prognostic, predictive, and treatment implications. Cell Stress Chaperones 2005, 10:86-103.

3. Jolly C, Morimoto Rl: Role of the heat shock response and molecular chaperones in oncogenesis and cell death. J Natl Cancer Inst 2000, 92:1564-1572.

4. Concannon CG, Gorman AM, Samali A: On the role of Hsp27 in regulating apoptosis. Apoptosis 2003, 8:61-70

5. Lanneau D, Brunet M, Frisan E, Solary E, Fontenay M, Garrido C: Heat shock proteins: essential proteins for apoptosis regulation. J Cell Mol Med 2008, 12:743-761.

6. Habich $C$, Burkart V: Heat shock protein 60 : regulatory role on innate immune cells. Cell Mol Life Sci 2007, 64:742-751.

7. Wu T, Tanguay RM: Antibodies against heat shock proteins in environmental stresses and diseases: friend or foe? Cell Stress Chaperones 2006, 11:1-12.

8. Rowley MJ, Karopoulos C: Heat shock proteins autoantibodies. In Autoantibodies. Edited by Peter JB, Shoenfeld Y. Amsterdam, The Netherlands: Elsevier Science B.V; 1996:336-342.

9. Rabczyński M, Adamiec R, Olszewska-Roczniak J: Antibodies anti-HSP 60/65 role in atherogenesis, arteriosclerotic plaque risk factor. Adv Clin Exp Med 2006, 15:933-939.

10. Pockley AG: Heat shock protein in health and disease: therapeutic targets or therapeutic agents? Expert Rev Mol Med 2001, 3:1-21.

11. Memarzadeh S, Berek JS: Advances in the management of epithelial ovarian cancer. J Reprod Med 2001, 46:621-630.

12. Hoskins WJ: Prospective on ovarian cancer: why prevent? J Cell Biochem 1995, 59(suppl.23):189-199.

13. Taylor DD, Gercel-Taylor C, Parker LP: Patient-derived tumor-reactive antibodies as diagnostic markers for ovarian cancer. Gynecol Oncol 2009, 115:112-120.

14. Berek JS, Schultes BC, Nicodemus CF: Biologic and immunologic therapies for ovarian cancer. J Clin Oncol 2003, 21(suppl.10):168s-174s.
15. Nossov V, Amneus M, Su F, Lang J, Janco JM, Reddy ST, Farias-Eisner R: The early detection of ovarian cancer: from traditional methods to proteomics. Can we really do better than CA-125? Am J Obstet Gynecol 2008, 199:215-223.

16. Taylor DD, Gercel-Taylor C: Tumor-reactive immunoglobulins in ovarian cancer: diagnostic and therapeutic significance? (rewiev). Oncol Rep 1998, 5:1519-1524.

17. Gagnon A, Kim JH, Schorge JO, Ye B, Liu B, Hasselblatt K, Welch WR, Bandera CA, Mok SC: Use of combination of approaches to identify and validate relevant tumor-associated antigens and their corresponding autoantibodies in ovarian cancer patients. Clin Cancer Res 2008, 14:764-771.

18. Gercel-Taylor C, Bazzett LB, Taylor DD: Presence of aberrant tumor-reactive immunoglobulins in the circulation of patients with ovarian cancer. Gynecol Oncol 2001, 81:71-76.

19. Anderson KS, LaBaer J: The sentinel within: exploiting the immune system for cancer biomarkers. J Proteome Res 2005, 4:1123-1133.

20. Nesterova M, Johnson N, Cheadle C, Cho-Chung YS: Autoantibody biomarker opens a new gateway for cancer diagnosis. Biochim Biophys Acta 2006, 1762:398-403.

21. Luborsky JL, Barua A, Shatavi SV, Kebede T, Abramowicz J, Rotmensch J: Antitumor antibodies in ovarian cancer. Am J Reprod Immunol 2005, 54:55-62.

22. Thorpe JD, Duan X, Forrest R, Lowe K, Brown L, Segal E, Nelson B, Anderson GL, McIntosh M, Urban N: Effects of blood collection conditions on ovarian cancer serum markers. PLoS One 2007, 2:e1281.

23. Dummer R, Mittelman A, Fanizzi FP, Lucchese G, Willers J, Kanduc D: Non-self-discrimination as a driving concept in the identification of an immunodominant HMW-MAA epitopic peptide sequence by autoantibodies from melanoma cancer petients. Int J Cancer 2004, 111:720-726.

24. Brichory F, Beer D, Le Naour F, Giordano T, Hanash S: Proteomics-based identification of protein gene product 9.5 as a tumor antigen that induces a humoral immune response in lung cancer. Cancer Res 2001, 61:7908-7912.

25. Tang R, Ko MC, Wang JY, Changchien CR, Chen HH, Chen JS, Hsu KC, Chiang JM, Hsieh LL: Humoral response to p53 in human colorectal tumors: a prospective study of 1209 patients. Int I Cancer 2001, 94:859-863.

26. Vogl FD, Frey M, Kreienberg R, Runnebaum IB: Autoimmunity against p53 predicts invasive cancer with poor survival in patients with ovarian mass. Br J Cancer 2000, 83:1338-1343.

27. Korneeva I, Bongiovanni AM, Girotra M, Caputo TA, Witkin SS: IgA antibodies to the $27-\mathrm{kDa}$ heat-shock protein in the genital tracts of women with gynecologic cancers. Int I Cancer 2000, 87:824-828.

28. Tang D, Khaleque MA, Jones EL, Theriault JR, Li C, Wong WH, Stevenson MA, Calderwood SK: Expression of heat shock proteins and heat shock protein messenger ribonucleic acid in human prostate carcinoma in vitro and in tumors in vivo. Cell Stress Chaperones 2005, 10:46-58.

29. Elpek GO, Karaveli S, Simsek T, Keles N, Aksoy NH: Expression of heat-shock proteins hsp27, hsp70 and hsp90 in malignant epithelial tumour of the ovaries: correlation with clinicopathologic factors and survival. APMIS 2003, 111:523-530.

30. Capello F, Rappa F, David S, Anzalone R, Zummo G: Immunohistochemical evaluation of PCNA, p53, HSP60, HSP10 and

MUC-2 presence and expression in prostate carcinogenesis. Anticancer Res 2003, 23:1325-1331.

31. Capello F: HSP60 and HSP10 as diagnostic and prognostic tools in the management of exocervical carcinoma. Gynecol Oncol 2003, 91:661.

32. Capello F, Bellafiore M, Palma A, David S, Marcianò V, Bartolotta T, Sciumè C, Modica G, Farina F, Zummo G, Bucchieri F: 60 kDa chaperonin (HSP60) is overexpressed during colorectal carcinogenesis. Eur J Histochem 2003, 47:105-110.

33. Lim R, Lappas M, Ahmed N, Permezel M, Quinn MA, Rice GE: 2D-PAGE of ovarian cancer: Analysis of soluble and insoluble fractions using medium-range immobilized pH gradients. Biochem Biophys Res Commun 2011, 406:408-413.

34. Kimura E, Enns RE, Alcaraz JE, Arboleda J, Slamon DJ, Howel SB: Correlation of the survival of ovarian cancer petients with mRNA expression of the 60-kD heat-shock protein HSP-60. J Clin Oncol 1993, 11:891-898.

35. Schneider J, Jimenez E, Marenbach K, Romero H, Marx D, Meden H: Immunohistochemical detection of HSP60-expression in human ovarian cancer. Correlation with survival in a series of 247 patients. Anticancer Res 1999, 19:2141-2146.

36. Trieb K, Gerth R, Windhager R, Grohs JG, Holzer G, Berger P, Kotz R: Serum antibodies against the heat shock protein 60 are elevated in patients with osteosarcoma. Immunobiology 2000, 201:368-376. 
37. Olejek A, Damasiewicz-Bodzek A, Bodzek P, Wielkoszyński T, Zamłyński J, Stołtny P, Skutil M: Concentrations of antibodies against heat shock protein 27 in the sera of women with ovarian carcinoma. Int J Gynecol Cancer 2009, 19:1516-1520.

38. Vidal Cl, Mintz PJ, Lu K, Ellis LM, Manenti L, Giavazzi R, Gershenson DM, Broaddus R, Liu J, Arap W, Pasqualini R: An HSP90-mimic peptide revealed by fingerprinting the pool of antibodies from ovarian cancer patients. Oncogene 2004, 23:8859-8867.

39. Abu-Hadid M, Wilkes JD, Elakawi Z, Pendyala L, Perez RP: Relationship between heat shock protein 60 (HSP60) mRNA expression and resistance to platinum analogues in human ovarian and bladder carcinoma cell lines. Cancer Letters 1997, 119:63-70.

40. Langdon SP, Rabiasz GJ, Hirst GL, King RJ, Hawkins RA, Smyth JF, Miller WR Expression of the heat shock proteins HSP27 in human ovarian cancer. Clin Cancer Res 1995, 1:1603-1609.

41. Mendez F, Sandigursky M, Kureekattil RP, Kenny MK, Franklin WA, Bases R: Specific stimulation of human apurinic/apyrimidinic endonuclease by heat shock protein 70. DNA Repair 2003, 2:259-271.

42. Nadin SB, Vargas-Roig LM, Cuello-Carrion FD, Ciocca DR: Deoxyribonucleic acid damage induced by doxorubicin in peripheral blood mononuclear cells: possible roles for the stress response and the deoxyribonucleic acid repair process. Cell Stress Chaperones 2003, 8:361-372.

43. Danieli MG, Candela M, Ricciatti AM, Reginelli R, Danieli G, Cohen IR, Gabrielli A: Antibodies to mycobacterial $65 \mathrm{kDa}$ heat shock protein in systemic sclerosis (scleroderma). J Autoimmun 1992, 5:443-452.

44. de Graeff-Meeder ER, Rijkers GT, Voorhorst-Ogink MM, Kuis W, van der Zee R, van Eden W, Zegers BJ: Antibodies to human hsp60 in patients with juvenile chronic arthritis, diabetes mellitus, and cystic fibrosis. Pediatr Res 1993, 34:424-428.

45. Hoppichler F, Lechleitner M, Traweger C, Schett G, Dzien A, Sturm W, Xu Q: Changes of serum antibodies to heat-shock protein 65 in coronary heart disease and acute myocardial infarction. Atherosclerosis 1996, 126:333-338

46. Frostegård J, Lemne C, Andersson B, van der Zee R, Kiessling R, de Faire U: Association of serum antibodies to heat-shock protein 65 with borderline hypertension. Hypertension 1997, 29:40-44.

47. Wick G, Perschinka H, Millonig G: Atherosclerosis as an autoimmune disease: an update. Trends Immunol 2001, 22:665-669.

48. Mayr M, Metzler B, Kiechl S, Willeit J, Schett G, Xu Q, Wick G: Endothelial cytotoxicity mediated by serum antibodies to heat shock proteins of Escherichia coli and Chlamydia pneumonia: immune reactions to heat shock proteins as a possible link between infection and atherosclerosis. Circulation 1999, 99:1560-1566.

49. Prohászka Z, Bánhegyi D, Ujhelyi E, Karádi I, Füst G: Antibodies against 60$\mathrm{kDa}$ heat-shock proteins in human immunodeficiency virus infection. Ann NY Acad Sci 1998, 851:94-98.

50. Prohászka Z, Duba J, Horváth L, Császár A, Karádi I, Szebeni A, Singh M, Fekete B, Romics L, Füst G: Comparative study on antibodies to human and bacterial $60 \mathrm{kDa}$ heat shock proteins in a large cohort of patients with coronary heart disease and healthy subjects. Eur I Clin Invest 2001, 31:285-292.

51. Prohászka Z, Duba J, Lakos G, Kiss E, Varga L, Jánoskuti L, Császár A, Karádi I, Nagy K, Singh M, Romics L, Füst G: Antibodies against human heat-shock protein (hsp) 60 and mycobacterial hsp65 differ in their antigen specificity and complement-activating ability. Int Immunol 1999, 11:1363-1370.

52. Handley HH, Yu J, Yu DT, Singh B, Gupta RS, Vaughan JH: Autoantibodies to human heat shock protein (hsp)60 may be induced by Escherichia coli GroEL. Clin Exp Immunol 1996, 103:429-435.

53. Metzler B, Schett G, Kleindienst R, van der Zee R, Ottenhoff T, Hajeer A, Bernstein $R, X u Q$, Wick G: Epitope specificity of anti-heat shock protein $65 / 60$ serum antibodies in atherosclerosis. Arterioscler Thromb Vasc Biol 1997, 17:536-541.

54. Birnie DH, Vickers LE, Hillis WS, Norrie J, Cobbe SM: Increased titres of antihuman heat shock protein 60 predict an adverse one year prognosis in patients with acute cardiac chest pain. Heart 2005, 91:1148-1153.

55. Pockley AG, Bulmer J, Hanks BM, Wright BH: Identification of human heat shock protein 60 (Hsp60) and anti-Hsp60 antibodies in the peripheral circulation of normal individuals. Cell Stress Chaperones 1999, 4:29-35.

doi:10.1186/1757-2215-7-30

Cite this article as: Bodzek et al:: Antibodies against Hsp60 and Hsp65 in the sera of women with ovarian cancer. Journal of Ovarian Research 2014 7:30.

\section{Submit your next manuscript to BioMed Central and take full advantage of:}

- Convenient online submission

- Thorough peer review

- No space constraints or color figure charges

- Immediate publication on acceptance

- Inclusion in PubMed, CAS, Scopus and Google Scholar

- Research which is freely available for redistribution 